\title{
Medical Social Work Practices after Sexual Assault against Women
}

\author{
Kadına Yönelik Cinsel Saldırı Sonrası Müdahalede Tıbbi Sosyal Hizmet \\ Uygulamaları
}

\author{
Semra Saruç*1, Hüsnünur Aslantürk ${ }^{2}$
}

\begin{abstract}
As a type of sexual violence, women are exposed to sexual assault more frequently than men. For this reason, intervention after sexual assault usually takes shape on women, and women come to the forefront in such practices. The need for health services for all dimensions of women exposed to sexual assault firstly increases the need for prioritizing interventions, not only physically in terms of diagnosis and treatment, but also components of psychological, emotional, social and economic well-being that are the nature of sexual assault. In this context, medical social work practices have an important place in the intervention of women exposed to sexual assault. In this general framework, the aim of this work is not only to discuss the importance of medical social work practices structured at the community, individual, group, and community level, but also with family, community, society, and not with women exposed to individual sexual assault.
\end{abstract}

Keywords: Sexual assault, woman, medical social work practices

\section{ÖZET}

Cinsel şiddetin bir türü olan cinsel saldırıya, kadınların erkeklere oranla daha fazla maruz kaldıkları bilinmektedir. Bu nedenle, cinsel saldırı sonrası müdahale genellikle kadınlar üzerine şekillenmekte, kadın bu tür uygulamalarda ön plana çıkmaktadır. Cinsel saldırıya maruz kalan kadınların, öncelikle her boyutuyla sağlık hizmetine olan ihtiyacı, sadece fiziksel olarak tanı ve tedavi boyutunda değil, cinsel saldırının doğası gereği psikolojik, duygusal, sosyal ve ekonomik anlamda sağlı̆̆ın bileşenlerini de ön plana çıkarıcı müdahalelere duyulan ihtiyacı arttırmaktadır. Bu bağlamda, cinsel saldırıya maruz kalan kadınlara yapılan müdahalede, tıbbi sosyal hizmet uygulamalarının önemli bir yeri bulunmaktadır. Bu genel çerçevede, bu çalışmanın amacı, sadece bireysel olarak cinsel saldırıya maruz kalan kadınla değil, ailesiyle, çevresiyle, toplumla bireysel, grup ve toplum düzeyinde yapılandırılan tıbbi sosyal hizmet uygulamalarının yeri ve önemini tartışmaktır.

Anahtar kelimeler: Cinsel saldırı, kadın, tıbbi sosyal hizmet uygulamaları

Received / Geliş tarihi: 18.01.2018, Accepted / Kabul tarihi: 19.03.2018

${ }^{1}$ Anadolu Üniversitesi Sağlık Bilimleri Fakültesi Sosyal Hizmet Bölümü

${ }^{2}$ Kocaeli Üniversitesi Sağlık Bilimleri Fakültesi Sosyal Hizmet Bölümü

*Address for Correspondence / Yazışma Adresi: Doç.Dr. Semra Saruç, Anadolu Üniversitesi Sağllk Bilimleri Fakültesi Sosyal Hizmet Bölümü Eskişehir -TÜRKIYE, E-mail: semrasaruc@gmail.com

Saruç ve Aslantürk. Kadına Yönelik Cinsel Saldırı Sonrası Müdahalede Tıbbi Sosyal Hizmet Uygulamaları. TJFMPC, 2018; $12(2)$ : $136-147$.

DOI: $10.21763 /$ tjfmpc.432550 


\section{GíRIŞ}

"İnsanın sosyal hayatta varoluş mekanı"1 olarak tanımlanan bedenin, en fazla önem verilen özelliklerinden biri de cinsiyettir. ${ }^{2}$ Bedene yönelen en ağır tahakkümlerden biri olan şiddet de, bu cinsiyet faktöründen etkilenmekte ve kadınlar hayatlarının her döneminde, farklı şiddet biçimleriyle yüz yüze gelme tehlikesini, erkeklere oranla daha yüksek düzeyde yaşamaktadır.

Günümüzde kadına yönelik şiddet, tüm dünyada mücadele edilen önemli bir sosyal sorun olarak gündemdeki yerini korumaktadır. Kadına yönelik şiddetin, tüm formları farklı şekillerde kadını etkilemesine rağmen, cinsel şiddet, fiziksel, ruhsal, duygusal, sosyal ve ekonomik etkileri olması nedeniyle özellikli bir yere sahiptir. Dünya Sağlık Örgütü, Dünya Şiddet ve Sağlık Raporu'nda ${ }^{3}$ cinsel şiddet, "bireyin rızası olmadan, baskı kullanarak ya da rızasının aranmayacağı durumlarda herhangi bir cinsel hareket, girişim, cinsel içerikli sözler ile fiziksel, ruhsal ve sosyal zarar görmesi" olarak tanımlanmaktadır. Aynı raporda, cinsel şiddet türleri de ayrıntılı bir şekilde tanımlanmıştır. Buna göre, evlilik içinde, beraberliklerde ya da yabancılar tarafindan gerçekleştirilen tecavüz, savaş esnasında sistematik olarak gerçekleştirilen tecavüz, cinsel sataşmalar ve saldırılar, engelli bireylerin, çocukların cinsel istismarı, evlenmeye zorlama, gebelikten korunma yöntemlerini kullanma hakkının engellenmesi, zorla düşük, bekâret muayeneleri gibi kadının cinsel bütünlüğüne yönelik saldırgan eylemler, bireylerin cinsel istismar amaciyla ticari yönden kötüye kullanılması, cinsel şiddet kapsamında değerlendirilmektedir.

Cinsel şiddetin bir türü olan cinsel saldırı ise, kullanılan zorlamaya göre farklı şekillerde ele alınır. Ülkemizdeki uygulamayı da kapsaması açısından, 5237 Sayılı Türk Ceza Kanunu'nun altıncı bölümünde yer alan "Cinsel Dokunulmazlığa Karşı Suçlar" başlığı altında yer alan 102. maddede yer verilen tanım belirleyici olacaktır. İlgili maddede cinsel saldırı "cinsel davranışlarla bir kişinin vücut dokunulmazlığını ihlal etmek" olarak tanımlanmıştır. Cinsel saldırı eylemi, iki farklı şekilde gerçekleşebilmektedir. İlk olarak cinsel saldırı, "vücuda organ ya da sair cismin giriși olmadan, vücut dokunulmazlığının ihlalini” içerirken, ikinci tür cinsel saldırıda ise "kişinin vücut dokunulmazlığının, vücuda cinsel organ veya sair bir cisim sokulmasıyla ihlal edilmesi" söz konusudur. Vajinal, anal ve oral yolla bir cisim ya da organ kullanılarak gerçekleştirilen saldırılar bu kapsamdadır". ${ }^{4}$ Görüldüğü gibi cinsel saldırı kişiye dokunmaktan, sarılmaktan tecavüze kadar geniş bir yelpazede değerlendirilen bir dizi durumu kapsamaktadır. Tecavüz ya da ırza geçme ise cinsel saldırının en uç noktasıdır ve "mağdurun rızası olmadan gerçekleşen penetrasyon" olarak tanımlanmaktadır. ${ }^{3}$

\section{Yaygınlık}

Cinsel saldırıya maruz kalma oranlarıyla ilgili veriler değerlendirildiğinde, toplumsal ve kültürel koşullar önemli bir değişken olarak karşımıza çıkmaktadır. Cinsel saldırıya maruz kaldığını açıklamanın, bir kadın için, içinde yaşadığ toplumun bakış açısından ve kültürel değerlerinden bağımsız olmadığı aşikârdır. Ayrıca doğası gereği, cinsel saldırıya maruz kalmanın, kadının fiziksel, duygusal, psikolojik, sosyal ve ekonomik hayatına etkileri de bu durumu çevresindekilerle paylaşma konusunda belirleyicidir. $\mathrm{Bu}$ noktada cinsel saldırıya maruz kalmakla ilgili istatistiki verileri, bu çerçevede değerlendirmek, gerçek tabloya ilişkin bir fikir verebilir. Bu tablonun vahametiyle ilgili olarak Davis ${ }^{5}$, oldukça az sayıda kadının yaşamları boyunca bir kez olsun cinsel saldırı girişimine, ya da cinsel saldırıya maruz kalmadığını söyleyebileceğini belirtmektedir.

Medeni kültürlerin hemen hemen hepsinde, cinsel saldırı ile karşılaşılmakla birlikte, görülme sıklığı toplumdan topluma önemli ölçüde farklılaşmaktadır. Bu noktada Amerika Birleşik Devletleri, cinsel saldırının, özellikle de tecavüzün en fazla görüldüğü toplumlardan biri olarak ön plana çıkmaktadır. ${ }^{6}$ Amerika'da, son yirmi yıllık dönemde tecavüz oranı, yüz bin kişide $\% 88$ $\operatorname{artmıştır~}^{7}$ ve her 6 dakikada bir kadına tecavüz edilmektedir. $^{8} \quad$ Kanada'da, $420 \quad$ kadınla gerçekleştirilen bir çalışmada, 16 yaşından itibaren araştırmaya dâhil olan kadınların yüzde 40'1, hayatlarının bir döneminde cinsel zorlama ile yüz yüze geldiklerini bildirmişlerdir. ${ }^{9}$

Çoğu toplumsal yapıda, farklı şekillerde olsa da genel olarak cinsel ilişkinin meşruiyet kazandığı bir kurum olarak, evlilik kurumu da kadına yönelik cinsel saldırının yaşandığı alanlardan biridir. $\mathrm{Bu}$ nedenle, ülkemizde "kol kırılır yen içinde kalır" bakış açısıyla, aile içinde var olan şiddete, özellikle de en mahrem alan olarak kültürümüzde kabul gören cinsel alana müdahale etmek yerine, bu tür sorunların eşler arasında çözümlenmesinin gerekliliğiyle ilgili bakış açısı sonucu, bu alana devlet tarafindan mümkün olduğu kadar az müdahale edilmesiyle ilgili yaklaşımın terk edilmeye başlandığı görülmektedir. ${ }^{10}$ Özellikle aile içinde meydana gelen şiddet ile ilgili tartışmalarda, ailenin "özel alan" olarak kabul edilmesi ve bu nedenle devletin bu konudaki sorumluluğunun sinırlandırılmasıla ilgili, literatürde yapılan tartışmalar sonucunda, ${ }^{11}$ evlilik içi tecavüzün birçok ülkede olduğu gibi ülkemizde de suç olarak tanımlanmasıyla birlikte, evlilik 
birliği içerisinde, erkeğin kadına karşı her türlü cinsel tahakkümünün olağan sayıldığı bakış açısı da değişmeye başlamıştır. Türkiye'de Kadına Yönelik Aile İçi Şiddet Araştırması ${ }^{12}$ (2014) sonuçlarına göre, evlenmiş kadınların yüzde 12'si, yaşamlarının herhangi bir döneminde eşleri ya da birlikte oldukları erkekler tarafindan, cinsel şiddete maruz kaldıklarını belirtmişlerdir. İngiltere'de de, en yaygın tecavüz şekli, kadınların şimdiki eşleri, eski eşleri ya da partnerleri tarafindan gerçekleştirilmektedir. Ayrıca, her yedi evli kadından birisi, eşleri tarafından cinsel ilişkiye zorlanmaktadır. ${ }^{13}$ Ülkemizde, 2015 y1lında 5340 kişi cinsel suçtan hüküm giymiştir. Cinsel suçtan hüküm giyenlerin oranı, tüm hükümlüler içinde \%3,1'dir. Cinsel suçlarda, \%98,9 oranında erkekler hüküm giymiş, dolayısıyla cinsel saldırılara en yüksek oranda kadınlar maruz kalmıştır. ${ }^{14}$

Cinsel saldırı, şiddet suçlarından en yaygın olanı, en hızlı artanı ve aynı zamanda en gizli kalanı olarak ön plana çıkmaktadır. ${ }^{15}$ Dünya genelinde gerçekleşen cinsel saldırılarla ilgili bilgiler, genel olarak emniyet güçleri, sağlık kuruluşları, sivil toplum kuruluşları ve yapılan araştırmalardan elde edilmektedir. $^{3}$ Ancak, cinsel saldırının kayıtlı sayısal verilerden yola çıkılarak değerlendirilmesi, genel epidemiyolojiyi anlamak açısından yetersiz kalmaktadır. $\mathrm{Bu}$ durum, cinsel saldırıların adli mercilere bildirilme oranının düşüklüğü ile ilgilidir. Çoğu araştırma tahminine göre, tecavüz girişimlerinin yalnız \%20 ile \%50'si resmi mercilere intikal etmektedir. 246 cinsel saldırı mağduru ile yapılan bir araştırmada, 100'ünün yaşadığ1 saldırıyı polise bildirmediği görülmüştür. ${ }^{6}$ Yine bir başka çalışmada, cinsel saldırı mağduru kadınların, \%90'ından fazlasının bu durumu adli mercilere bildirmediği dikkat çekmektedir. ${ }^{16}$ Amerika'da ise Ulusal Suç Araştırması sonuçlarına göre, gerçek tecavüz olaylarının polise duyurulanlardan iki katı fazla olduğu görülmüştür. ${ }^{17}$ $\mathrm{Bu}$ durumun nedeniyle ilgili olarak, bildirilen olguların daha çok bir yabancının topluma açık bir yerde birdenbire ve şiddetli saldırısı ile karşı karşıya kaldıkları ya da zorla eve giren birinin, tecavüzle birlikte silah kullandığı ve yaralama ile sonuçlanan saldırılardan oluştuğu görülmektedir. Yani, daha çok klasik olarak toplum tarafindan "cinsel saldırı" olarak tanımlanan ve kabul gören olguların bildiriminin daha yüksek olduğu dikkat çekmektedir. Aynı zamanda saldırganın kendisinden intikam alma ihtimali, mağdura inanılmayacağı, rezil olma korkusu, suçluluk, ailesini ya da arkadaşlarını koruma duygusu gibi sebeplerden dolayı cinsel saldırıların bildiriminin düşük olduğu görülmektedir. Ayrıca, cinsel saldırganın mağdurun çevresinden ya da ailesinden birisi olması durumunda, ya da cinsel saldırıya fiziksel şiddet yerine sözlü tehdit gibi diğer şiddet türlerinin eşlik ettiği durumlarda, bildirim oranlarının daha düşük olduğu da dikkat çekmektedir. ${ }^{6}$

\section{Cinsel Saldırıya Yönelik Yaklaşımlar}

Cinsel saldırı, doğası gereği, tıp, halk sağlığı, aile hekimliği, hukuk, psikoloji, hemşirelik, sosyal hizmet gibi birçok disiplini doğrudan ilgilendiren bir fenomendir. Hukuk, cinsel saldırının hukuksal boyutuna, tıp, cinsel saldırıya maruz kalan ve cinsel saldırıda bulunan kişinin tüm yönleriyle sağlık durumuna, halk sağlığı, cinsel saldırı olgusunun toplumsal sağlığa etkilerine, aile hekimliği, cinsel saldırıya maruz kalma ile ilgili koruyucu ve önleyici sağlık hizmetlerine, psikoloji, her iki tarafin da psikolojik durumuna, hemşirelik cinsel saldırıya maruz kalan kadına verilen sağlık ve bakım hizmetine, sosyal hizmet ise "çevresi içinde birey" anlayışını yansıtan ve bireyi bir bütün olarak ele alan biyo-psiko-sosyal boyutuna odaklanır. Her disiplin, kendi çalışma alanıyla ilgili kendi bilimsel bilgi temeline dayanarak, farklı bakış açılarıyla cinsel saldırıyı ele almaktadır. Bu bağlamda, literatürde cinsel saldırı konusunda, birçok farklı yaklaşım olduğu dikkat çekmektedir. Scully, ${ }^{6}$ cinsel saldırı, özellikle de tecavüzle ilgili yaklaşımları, beş genel başlık altında sınıflandırmaktadır:

Hastalık Modeli: $\mathrm{Bu}$ modelde cinsel saldırı, akıl sağlığının yerinde olmayışının ve genellikle denetim altında tutulamayan cinsel bir dürtünün sonucu olarak ele alınmaktadır. Cinsel saldırıda bulunma davranışını, bir hastalık ve kişinin iradesi ile denetim altına alınmayan bir durum olarak ele almak, cinsel saldırıda bulunan kişiyi davranışından sorumlu tutmamak sonucuna ulaşmayı beraberinde getirmektedir.

Psikoanalitik Model: Bu modelde, cinsel saldırıya maruz kalan bireyleri, kişisel özelliklerine ya da içinde bulundukları koşullara göre sınıflandırma yaklaşımı dikkat çekmektedir. Örneğin Lither (1973), bilinçli ya da bilinç dışı olarak tecavüz edilme isteği taşımayan "gerçek kurbanlar" ile içten içe tecavüzle ilgili mazoşist bir ihtiyaç içinde olan "profesyonel kurbanları" birbirinden ayırır. Profesyonel kurbanlar, bilinç dışı bir istek sonucunda gizli bir şekilde kendilerini tecavüzcüye sunarak, tecavüzcüyle farkında olmadan bir işbirliği içine girerler. ${ }^{6}$

Psikopatolojik Model: $\mathrm{Bu}$ modelde ise cinsel saldırıyı bireysel bir sorun olarak görme eğilimi ön plandadir. $\mathrm{Bu}$ ise bir toplumsal sorun olarak günümüzde kabul gören cinsel saldırının sebebinin, bireyde aranmasına ve kültürel ve toplumsal yapının etkilerinin göz ardı edilmesine yol açmaktadır. Cinsel saldırı "hasta" erkekle sınırlı bir bağlamda ele alındığında, çözüme de bu hastalığ tedavi etmekle ulaşılabilir. $\mathrm{Bu}$ davranıştan 
korunmak için, kadınların tek çaresi ise bu hasta erkeklerden uzak durarak kendilerini korumaktır.

Feminist Model: Psikopatolojik modele tepki olarak geliştirilen feminist modelde, cinsel saldırının toplumsal ve kültürel altyapısını açıklayacak alternatif bir açıklama önerilmektedir. Cinsel saldırıyı, kadın erkek ilişkileri çerçevesinde çözümleyen bu modelde tecavüz, cinsel zorlamanın sadece erkekler tarafından uygulanan bir biçimi olarak ele alınır. $\mathrm{Bu}$ modelde tecavüz, kadınlara yönelik uygulanan bir toplumsal denetim mekanizmasıdır. Toplumsal ve kültürel olarak var edilen cinsiyetçi bakışın altında, kadını, erkeğin "malı" olarak gördüğü için, kadın bedenine zorla sahip çıkılmasının yani cinsel saldırının haklılaştırılması yatmaktadır.

Antropolojik Model: Bu modelde, cinsel saldırının daha çok kültürel tutumlara, kadın ve erkek cinsi arasındaki iktidar ilişkilerine, kadınların erkeklere kıyasla bulundukları toplumsal ve ekonomik statüye ve toplumdaki diğer şiddet biçimlerinin miktarına bağlı olduğu belirtilmektedir.

Cinsel saldırı, karmaşık bir toplumsal içeriğe sahip bir olgudur. Bu nedenle onu sadece "cinsel saldırı" olarak diğer toplumsal olgulardan izole bir şekilde ele almak, bu olgunun analizinde yanlış yollara sapılmasına neden olabilir. ${ }^{5}$ Bununla birlikte, kadına yönelik cinsel saldırının en önemli kaynağının, her türden cinsiyetçi yaklaşımlar olduğu söylenebilir. Benzer bir bakış açısıyla Arın'da, cinsel şiddetin kaynağının, "kadın ve erkek arasındaki güç dengesizliği” olduğunun altını çizmektedir. ${ }^{18}$ Tecavüz konusunda uzmanlaşmış feministlerden Pouline Bart ve Susan Brownmiller, cinsel saldırının "tüm erkeklerin, kadınların tümünü sindirmek amacıyla onları sürekli korku içinde tuttuğu bilinçli bir süreç" olduğu görüşünü paylaşmaktadır. ${ }^{17}$

Cinsel saldırı mağdurlarıyla çalışan sosyal hizmet uzmanı, planladığı tıbbi sosyal hizmet uygulamalarında, sosyal hizmetin eklektik bilgi temelinden hareketle, çalıştığı vakanın cinsel saldırı ile çalışmanın genel özellikleri ve seçeceği yaklaşımın bu durumu açıklama gücünü göz önünde bulundurarak uygun yaklaşımı seçer. Diğer yandan, uygulamalarını temellendireceği yaklaşımı belirlerken, sosyal hizmet uzmanı müracaatçının "biricik" ve "tek" olduğu ilkesinden uzaklaşmadan hareket etmelidir. Her cinsel saldırı vakası kendine has özellikler taşımakta, her cinsel saldırı mağduru kadın da, kendi biricik ve tek sürecini yaşamaktadır. Bu süreçte dikkat edilmesi gereken diğer bir hususta, mağdurun cinsel saldırı sonras1 bulunduğu evre ve bu bağlamdaki ihtiyaçlarıdır. Kriz evresinde bulunan bir mağdura uygulanacak sosyal hizmet müdahalesinde, krize müdahale yaklaşımı ön planda iken, uzun dönem evrede psikanalitik modelden faydalanabilir. Ayrıca, sosyal hizmet uzmanı cinsel saldırı mağdurlarıyla çalışırken, mikro, mezzo ve makro boyutta sosyal hizmetin temel rollerinden olan savunuculuk rolü gereği feminist bakış açısını da çalışmalarına yansitır.

\section{Cinsel Saldırı Sonrası Müdahale ve Tıbbi Sosyal Hizmet Uygulamaları}

Literatürde, cinsel saldırıya maruz kalmanın bir sağlık problemi olduğunun, kısa ve uzun dönemde çeşitli sağlı sorunlarına sebep olabileceğinin altı çizilmektedir. $\mathrm{Bu}$ sağlık sorunları, istenmeyen gebelik ve cinsel yolla bulaşan hastalıklar dahil olmak üzere, cinsel sağlık ve üreme sağlığ1 sorunları, ruh sağlığı sorunları, fiziksel yaralanmalar ve toplumsal dişlanma olmak üzere genel olarak dört başlık altında özetlenebilir. ${ }^{3,19-21}$ Özellikle cinsel saldırı sonucunda meydana gelen gebelikler ve eşlik eden jinekolojik sorunlar, bir yandan fiziksel sağlığ 1 tehdit ederken, bir yandan da mağdurun ruhsal duygusal ve sosyal hayatını etkileyen sağlık sorunlarına yol açmaktadır. Gebelik durumu olmasa dahi, cinsel saldırı mağdurlarının ruhsal ve sosyal açıdan da etkilendiği bilinmektedir. $^{22,23}$ Tecavüz sonrası dönemde, cinsel saldırı mağdurlarının post travmatik stres bozukluğu yaşama durumunun yüksek olduğu ve psikolojik olarak patoloji görülme durumunun s1k olduğu görülmektedir Aynı zamanda yaşanan post travmatik stres bozukluğunun, fobik tepkiler ve dissosiyatif bozukluklarla da ilişkili olduğu ve bu dönemdeki bireylerin borderline benzeri bir dizi semptom sergilediği de anlaşılmaktadır. ${ }^{22}$ Cinsel saldırıya uğrayan ve uğramayan bireylerin, psikolojik durumlarının karşılaştırıldığı bir çalışmada, cinsel saldırıya uğrayan kadınların, sonraki bir yıllık dönemde cinsel saldırı mağduru olmayan gruba kıyasla daha yüksek düzeyde kayg1, korku, şaşkınlık ve şüphe yaşadıkları sonucuna ulaşılmıştır. ${ }^{24}$

Cinsel saldırı sonrası içinde bulunduğu çevrenin ve kültürün cinsel saldırıya bakış açısı ve bu duruma ilişkin kabulü, cinsel saldırı mağdurunun sürece ilişkin uyumunu etkilemektedir. Cinsel saldırı mağdurlarının, tecavüz sonrası dönemde sosyal uyum düzeylerinin bu durumdan etkilendiği, özellikle saldırıyı izleyen ilk birkaç ay içerisinde sosyal uyum düzeylerinde önemli ölçüde azalma olduğu, devam eden dönemde de uyum sorunu yaşanmaya devam eden alanın iş hayatı olduğu görülmektedir. Ayrıca, bu dönemde akrabalarla ilişkilerin içeriğinin de sosyal uyum düzeyi üzerinde önemli etkisi olan bir faktör olduğu dikkat çekmektedir. ${ }^{25}$

Mağdurlar, doğrudan maruz kaldıkları suç sonrasında, acil müdahale ya da daha sonraki 
süreçlerde fiziksel ve ruhsal tedavi almak amaciyla da sağlık kuruluşuna başvurabilir. Bu nedenle, özellikle sağlık alanı ve bu alanda çalışan profesyoneller, cinsel saldırı mağdurlarının doğrudan ya da yönlendirme sonucunda ilk iletişim kurdukları kişiler olmaları nedeniyle özellikli bir yere sahiptirler. ${ }^{26}$

Scully, ${ }^{6}$ cinsel saldırıyı ve özellikle tecavüzü son otuz kırk y1llık dönemde, alkolizm, uyuşturucu bağımlılığı gibi tıbbın çalışma alanına giren sosyal sorunlardan biri olarak ele almaktadir. Cinsel saldırının sosyal yönüne yapılan bu vurgu, cinsel saldırı mağdurlarını ve cinsel saldırıda bulunanları, tıbbi sosyal hizmet içinde öncelikli bir konuma taşımaktadır. Cinsel saldırıya maruz kalmak, bir yandan korku verici bir yandan da hayatın sonlanmasına kadar varabilecek zor bir deneyimdir. $\mathrm{Bu}$ nedenle mağdurların fiziksel sağlıklarının yanında, psiko-sosyal danışmanlık almaları da önerilmektedir. Cinsel saldırı sonrası, mağdurlar ve aileleri ya da eşlerinin de ayrı, ayrı dâhil oldukları bir danışmanlık hizmetine sağlık sistemi içinde ulaşmaları önemlidir. ${ }^{27} \mathrm{Bu}$ çerçevede, hastanelerde hizmet veren tıbbi sosyal hizmet birimleri, ya da acil ve krize müdahale birimleri aracılığıyla, sosyal hizmet uzmanı tarafindan sunulan tıbbi sosyal hizmet uygulamaları, cinsel saldırı sonrası müdahalenin olmazsa olmazlarındandır. Tibbi sosyal hizmet "ayaktan ya da yatarak tedavi gören hastaların tıbbi tedaviden etkin bir şekilde yararlanması, sosyal sağlığının korunması ve geliştirilmesi, tedavi sürecinde hastanın ailesi ve çevresi ile ilişkilerinin düzenlenmesi, tedavi sürecini etkileyen psikososyal ve sosyo-ekonomik sorunlarının zamanında çözümlenerek, sosyal işlevselliğinin yeniden kazanması amaciyla yürütülen sosyal hizmet müdahalesi"dir. ${ }^{28}$ Tibbi sosyal hizmetin uygulama alanlarından biri de kadına yönelik şiddet, dolayısıyla cinsel saldırıyı kapsayacak şekilde cinsel şiddet mağdurlarıdır. Krize müdahale birimleri ise acil servislerde oluşturulan ve öncelikli olarak acil servise gelen her türlü intihar girişimi vakalarında ve diğer kriz durumlarında bireye ve ailesine psikososyal destek sağlamak amacıyla Sağlık Bakanlığı'na bağlı hastanelerde kurulan birimlerdir. Krize Müdahale Birimleri, 2004 yılında Sağlık Bakanlığı Ruh Sağlığı Dairesi Başkanlığı tarafindan "Acil Serviste İntihar Girişimlerine Psikososyal Destek ve Krize Müdahale Programı" ile 30 ilde pilot çalışması yapılan hastanelerin acil servislerinde kurulmuştur. Şiddet te, Krize Müdahale Biriminin çalışma alanlarından biri, dolayısıyla bir kriz durumu olarak tanımlanmıştır. ${ }^{29}$ Ancak, Krize Müdahale Birimleri tüm hastanelere yaygınlaştırılamamıştır. Dolayısıyla bu birimlerin bulunmadığı hastanelerde sosyal hizmet uzmanlarının tıbbi sosyal hizmet birimlerinde görev yaparken, cinsel saldırı mağdurlarıyla çalıştıklarının altı çizilmelidir.

Krize müdahalede, bir diğer vurgulanması gereken nokta ise ekip çalışmasıdır. Cinsel saldırı mağdurlarına verilen sağlık hizmeti kapsamındaki ekip üyeleri, acil hekimi, psikiyatr, psikolog, sosyal hizmet uzmanı, hemşire, idari personelden krize müdahale ekibinin içinde yer alan çalışanlardan oluşmaktadır. Ekip üyelerinin mağdur ile çalışmalarını kendi görev alanlarıyla sınırlandırmaları, mağdur ile çalışırken önemli konulardan biridir. Görev alanı içine girmeyen, mağdurun özel hayatına ilişkin konuların ekipte yer alan sağlık personeli tarafindan bilinmemesi "gizlilik" ilkesinin temel prensiplerdendir. ${ }^{26} \mathrm{Bu}$ çerçevede mağdurlara karşı yargılayıcı olmayan, duyarlı bir yaklaşımla empati kurularak destek sağlanmalıdır.

Genel olarak bu alanda çalışan profesyonellerin ve bu ekibin bir parçası olarak sosyal hizmet uzmanlarının, empatik destek sunmak ve iyi bir dinleyici olmak için sahip olması gereken özellikler şu şekilde sıralanabilir: ${ }^{30}$

- Yasal, tıbbi prosedürler hakkında bilgi kaynağına sahip olmak,

- Tecavüze uğrayan kadın ve çevresi arasında arabulucu olmak,

- Gerçekçi yaklaşım. Tecavüze karşı vermiş olduğu tepkilerin normal olduğunu bilmesini sağlamak,

- İlişkiyi başlatıcı. Özellikle bu süreç boyunca mağduru aramayı içerir. $\mathrm{Bu}$ aşamada, ona ilginin kendisinin refahı için ve sosyal hizmet uzmanının ise kendisini dinlemek için olduğunu bilmesini sağlamak,

- Yeniden düzenleyici. Hislerini ve algılarını değiştirmesini sağlamak, kendini suçlama ve suçluluk duygusunu öfkeye, güçsüzlük duygusunu ise kontrole dönüştürmek,

- Kaynaklarla bağlantı kurucu. İhtiyaçlarını toplumda var olan kaynaklarla ve kişisel kaynaklarla karşılamasını sağlamaktır.

Tıbbi sosyal hizmet uygulamalarında da engellilik, korunmaya muhtaç çocuk, yaşlılık, suçluluk gibi diğer sosyal hizmet alanlarında olduğu gibi birey, grup ve toplum düzeyinde yapılan uygulama esastır. Sosyal hizmet uygulamalarında, sorun alanını sadece cinsel saldırıya uğramış kadın çerçevesinde ele almaktan ziyade "çevresi içinde birey" anlayışından hareketle, kadının eşi ve/veya ailesi, arkadaşları, iş ortamı, içinde bulunduğu çevre ve en nihayetinde toplumsal olarak ele alınmaktadır.

$\mathrm{Bu}$ bağlamda, cinsel saldırı sonrası müdahalede tıbbi sosyal hizmet uygulamalarının tartışılacağı bu 
bölümde cinsel saldırı mağdurları ile gerçekleştirilen sosyal hizmet müdahalesi birey, grup ve toplum; diğer bir ifadeyle mikro, mezzo ve makro düzeyde ele alınmıştır.

\section{Cinsel Saldırı Mağdurlarıyla Mikro Düzeyde Tıbbi Sosyal Hizmet Uygulamalart}

Öncelikle bu alanda çalışan ve farklı şekillerde sağlık hizmeti çerçevesinde cinsel saldırı mağdurlarına müdahale eden meslek elemanlarının, ilk olarak kabul etmesi gereken nokta "kurban olmadığınız sürece cinsel saldırının etkilerini anlamanızın aşırı derecede zor" olduğu ${ }^{30}$ ve iyileşmenin "bireysel bir süreç" 27 olduğudur. $\mathrm{Bu}$ nedenle cinsel saldırı mağduru kadınlarla gerçekleştirilecek sosyal hizmet müdahalesine mikro düzeyden başlanması önemlidir.

Cinsel saldırıya maruz kalmıș kadınların çoğu "tecavüz travma sendromu"(rape trauma syndrome) yaşamaktadır. Cinsel saldırının bir travma olarak ele alınması ve iyileşme sürecinin de farklı aşamalardan geçerek gerçekleştiğini kabul ederek başlamak, bu alanda yapılacak sosyal hizmet müdahalesinin sistematize edilmesi açısından önemlidir. Mağdurun iyileşme sürecinin hangi aşamasında olduğunu bilmek, uygulama yapacak sosyal hizmet uzmanının nereden başlayacağını bilmesi açısından önemlidir. Katz, ${ }^{30}$ cinsel saldırı sonrasındaki iyileşme evresini; kriz evresi, kısa dönem evre ve uzun dönem ya da bütünleşme evresi olarak üç farklı evrede ele almaktadır:

1. Kriz Evresi: Cinsel saldırının hemen sonrası dönem, genellikle kriz evresidir. Bu dönemde cinsel saldırıya maruz kalmış kadın şok, öfke, anksiyete, inkâr gibi birçok deneyimi aynı anda yaşamaktadır. $\mathrm{Bu}$ dönemde mağdurun en temel ihtiyaçları tıbbi bakım ve tedavi, fiziksel ve psikolojik olarak güvende hissetmektir. Saldırganın tekrar geri dönmesinden korkan kadın, güvenliğinin sağlandığından emin olmak ister. Ancak bu evrede mağdur henüz kendisine tam olarak neler olduğunun farkında olmayabilir. Mağdurlar arasında bu dönem çevreye verilen tepkiler farklılaşabilir. Kimisi ağlarken, kimisi gülebilir, titreme, huzursuzluk gibi davranışlar sergileyebilirler. ${ }^{30}$

Tibbi sosyal hizmet uygulamalarında gerçekleştirilecek mikro müdahalelerde, sosyal hizmet uzmanı genel olarak kriz evresinde olan mağdurlarla karşılaşacaktır. Cinsel saldırı, birçok kaynakta yaşamı etkileyen bir kriz durumu olarak ele alınır. ${ }^{31}$ Literatürde bir çok farklı şekilde açıklanan kriz "birey tarafindan zararlı, tehditkar ya da yoğun ölçüde üzücü olarak algılanan ve süregelen baş edebilme metotları ile çözülemeyen, stresli ya da travmatik olay ya da olaylar dizisi" olarak tanımlanabilir. ${ }^{32}$ Lindemann ve Caplan tarafindan ilk kez kullanılan kriz kavramı, daha 1960'l1 y1llardan itibaren, sosyal hizmet alanında da kullanılmaya başlanmıştır. ${ }^{33}$ Akut ve belli bir süre ile sınırlı bir denge bozukluğu olan kriz durumunda, homeostasis bozulmuş ve buna bağlı olarak birey kendini tehlikede hissetmektedir. ${ }^{34}$ Krize müdahale ise bireyin kriz olarak tanımlanan durumdan önce sahip olduğu fonksiyonelliğine dönmesi üzerine kurulu kisa süreli bir müdahaledir. ${ }^{35}$ Krize müdahalenin "duygusal ve çevresel alandaki acil ilk yardımla bireyin ve çevrenin acısının azaltılması" ve "kriz esnasında bireyin uyum ve mücadele gücünün kuvvetlendirilmesi” olmak üzere iki temel amacı vardır. ${ }^{31}$ Cinsel saldırı sonrasında sağlık kuruluşuna gelen kadına da bu kriz evresinde yapılacak müdahale, yaşadığı olaydan kaynaklanan acının azaltılması amacıyla, ilk yardımın yapılması ve sonrasında eski fonksiyonelliğine tekrar dönmesini sağlamaktır.

Krize müdahalenin aşamaları, krize yol açan durumun değerlendirilmesi, kriz durumu hakkında başvuranın bilgilendirilmesi, sorunun kısımlara ayrılarak çözümlenmesi ve tedavi sürecinin uygulanması olmak üzere dört temel adımdan oluşmaktadır. ${ }^{33}$ Cinsel saldırı mağdurlarıyla gerçekleştirilen tıbbi mikro düzeyde sosyal hizmet uygulamalarında da, cinsel saldırı sonrasındaki iyileşmenin evrelerinde mağdurun sergilediği davranışlar ve sergilediği özellikler ile krize müdahalenin aşamaları uyumlu bir çizgide yol alır.

Cinsel saldırı sonrasında mağdurların ilk uğrak noktalarından biri sağlık kuruluşlarıdır. ${ }^{26}$ Özellikle resmi mercilere intikal etmiş cinsel saldırılarda mutlaka mağdurun muayenesi için sağlık kuruluşuna getirilmesi sağlanmaktadır. Bu bağlamda, sosyal hizmet uzmanının da ilk fonksiyonu mağdurun fiziksel güvenliğinin sağlanması konusunda ona destek vermek ve ardından mağdur ile çevresi arasında arabuluculuk etmektir. Bu noktada sosyal hizmet uzmanı, cinsel saldırının faili ve gerçekleşme şekli ile ilgili de ayrıntılı bilgiye sahip olmalıdır. $\mathrm{Bu}$ yolla failin mağdurun eşi, aile üyelerinden ya da çevresinden birisi olmasi durumunda kendini ve sosyal hizmet müdahalesini bu çerçevede konumlandırmayı başarma şansı artabilir. Mağdurun ihtiyaçlarının saptanması ve sıraya konulması aşamasında bire bir mağdurla çalışan sosyal hizmet uzmanı, olası seçenekleri ile ilgili mağduru bilgilendirir. ${ }^{30} \mathrm{Bu}$ aşamada, özellikle dikkat edilmesi gereken nokta mağdurun içinde bulunduğu fiziksel ve psikolojik durumdur. Müdahalenin planlanabilmesi için mağdurla birlikte fiziksel ve psikolojik olarak ihtiyaç belirlemesi, arabuluculuk ya da psiko-sosyal destek gibi uygulamalar gerçekçidir. Çok ağır fiziksel ve cinsel şiddet görmüş bir mağdurun, o an 
içinde bulunduğu durum saptanarak yola çıkılmalı ve sosyal hizmet uygulamalarında önemli bir yeri olan ve kaynağını Gestalt terapiden alan "şimdi ve burada" ilkesi çerçevesinde hareket edilmelidir. Bu bağlamda, cinsel saldırı mağdurunun "şu anda" yaşadığı ya da yaşamakta olduğu duygularını ifade etmesine çalışılır. ${ }^{36}$

2. Kısa Dönem Evre: Cinsel saldırıyı takip eden iki ile altı hafta içinde ortaya çıkan bu dönemde, cinsel saldırının etkileri net olarak görülmeye ve bu durum mağdurun hayatını kontrol etmeye başlar. Mağdur, bu evrede evini taşımak, telefon numarasını değiştirmek gibi fiziksel, duygusal ve davranışsal olarak hayatında birçok değişikliği yapabilir. Aynı zamanda bu dönemde travma fobileri (phobias as a result of a trauma) olarak bilinen geceleri yalnız uyuyamama, yalnız dışarı çıkmaktan korkma, olağan üstü güvenlik önlemleri alma gibi fobik tepkiler sergileyebilir. $\mathrm{Bu}$ dönemdeki diğer tepkiler; kabus görme, sinirli ruh hali, ruhsal durumdaki değişiklikler, vajinal enfeksiyonlar, iştahın değişmesi gibi fiziksel tepkilerdir. Genel olarak özetlendiğinde, bu dönemde cinsel saldırı mağduru kadının enerjisinin büyük bir bölümü, cinsel saldırı ile mücadele etmekle geçer ve bu durumun hayatı üzerindeki etkileri ile ilgili farkındalığı artar. Duygusal olarak kadın suçlulukla ve kendini ayıplama ile mücadele edebilir. Kadın, cinsel saldırıyı kafasında tekrar tekrar yaşar ve bu durumdan kaçınması için neler yapması gerektiğini düşünür. Eğer kızgınlığını ifade edemezse, kendisini depresif hisseder ve içe kapanır. ${ }^{30} \mathrm{Bu}$ dönemde sosyal hizmet uzmanı krize müdahalenin, mağdurun mücadele gücünü arttırmasıla ilgili amacina hizmet edecek uygulamalar üzerinde yoğunlaşır. Bu noktada mağdur, mücadele etmek için desteğe ihtiyaç duyar.

$\mathrm{Bu}$ evrede sosyal hizmet müdahalesi, cinsel saldırı mağduruna yaşadığı farklı duygularla baş etmesinde destek olmak üzerine kurulur. $\mathrm{Bu}$ dönemde hayatının cinsel saldırıdan önceki haline birden bire dönmesini bekleyen kadınla yapacağ1 bireysel müdahalede, sosyal hizmet uzmanı gerçekçi olmalı, sadece ümit vermek yerine mağdurun gösterdiği tepkilerin normal olduğunu bilmesini sağlamalı ve bu konudaki şüphelerinin giderilmesinde yardımcı olmalıdır. Cinsel saldırıyı tekrar tekrar konuşmanın iyileşme süreci için olmazsa olmaz olmadığının, ancak iyileşme süreci için önemli bir adım olduğunun farkında olan sosyal hizmet uzmanı, mağdurun destek ve danışmanlık hizmetlerini kullanması ile ilgili onu bilgilendirmeli ve yüreklendirmelidir. Ayı zamanda mağdurun sosyal destek mekanizmalarının da etkin olarak kullanılmasıyla ilgili olarak mağduru desteklemelidir. Mağdur ile olumlu bir ilişkinin başlaması için uzman, bireysel müdahalelerinde desteğini tekrar tekrar sunmalıdır. ${ }^{30}$
3. Uzun Dönem Evre (Bütünleşme Evresi): İyileşme sürecinin son evresi olan bütünleşme evresi adaptasyonu içerir. Ancak bu evrenin, cinsel saldırıya karşı yeni bir travmanın gelişmediği durumlarda ortaya çıktığının altının çizilmesi gereklidir. Bütünleşme evresinde cinsel saldırı mağduru kadın, yaşadığı bu deneyimi hayatına başarıyla geçirmeye başlar. Artık maruz kaldığı cinsel saldırı kişinin hayatını yönetmez ve mağdur sürekli cinsel saldırıyla mücadele etmez. Son evrede mağdur kendini hayatında bir dizi değişiklik yapmış olarak bulur. Hatta cinsel saldırının onun hayatındaki etkisini kabullenmeyen aile üyeleriyle ya da arkadaşlarıyla görüşmeyi bile bırakabilir. Bu dönemde uzman, mağdurun cinsel saldırı sonrasında hayatında yapmış olduğu değişimleri gözden geçirmesine yardımcı olur. Kritik olan nokta ise yapılan müdahalenin suçlayıcı ya da utandırıcı unsurlar içermemesidir. ${ }^{30}$

Mikro düzeyde gerçekleştirilen müdahalelerde, cinsel saldırı mağduru ile bire bir çalışan sosyal hizmet uzmanı öncelikle genel olarak mağdurların genel bireysel özellikleri ve cinsel saldırı sonrası dönemde yaşadıkları muhtemel evrelerin üzerinde önemle durarak değerlendirir. $\mathrm{Bu}$ düzeyde çevresi içinde değerlendirilen mağdurla gerçekleştirilen çalışmada ailesi, arkadaşları ve çevresi tarafindan kabul edilen ve desteklenen mağdurun daha az psikolojik stres yaşadığı göz önünde bulundurulur. Toplumsal entegrasyonun sağlandığı ve bireyin cinsel saldırı öncesi sosyal işlevselliğine dönmek için çabaladığı bu dönemde, sosyal hizmetin temel rollerinden olan danışmanlık işlevi altında tanımlanan "muhtedir kılıcı" rolü çerçevesinde çalışmalarını yürütür. ${ }^{37}$ Mikro düzeyde bireyin güçlendirilmesinin hedef alındığ 1 bu işlev ve rolde sosyal hizmet uzmanı, cinsel saldırı mağduru kadınlara "kendi hayatları ve koşulları üzerinde büyük bir kontrol kazanmaları için” yardım eder. Mikro düzeyde güçlendirmenin daha çok kişisel ya da psikolojik düzeyine odaklanan sosyal hizmet uzmanı, güven geliştirme, benlik saygısının arttırılması ve beceri geliştirmeyi hedefler. ${ }^{38}$

\section{Cinsel Saldırı Mă̆durlarıyla Mezzo Düzeyde Tıbbi Sosyal Hizmet Uygulamaları}

Sosyal hizmet uygulamalarının temel bileşenlerinden biri olan grup çalışması, "ortak özellikleri, nitelikleri veya deneyimleri olan bireylerin oluşturduğu bir grup içinde, karşılıklı yardımı güçlendiren" bir yöntem olarak tanımlanmaktadır. ${ }^{32}$ Cinsel saldırı mağdurlarıyla gerçekleştirilen grup çalışmalarında da, cinsel saldırı ve sonrası süreçteki deneyimlerin paylaşılması, mağdurların karşılıklı olarak birbirlerinden yardım almaları ve nihai olarak hem bireysel hem de grup düzeyindeki değişimi 
gerçekleştirebilmelerinin

amaçlanmaktadır.

Sosyal hizmet uygulamalarında mezzo düzeyde grup çalışmaları genel olarak tedavi ve görev grupları olarak iki farklı şekilde gerçekleştirilmektedir. ${ }^{37-39}$ Kişiler arası ve sosyal ilişkileri geliştirmek amacıyla grup üyelerinin sosyal işlevselliğini arttıran sosyo-eğitsel "tedavi grupları" ve sosyal değişim, süpervizyon ve eğitime odaklanan "görev grupları". ${ }^{40}$ Tedavi gruplarında, grup üyelerinin değişimine yardımcı olmak esastır. ${ }^{40}$ Tedavi gruplarına eğitim, gelişim, iyileştirme, sosyalizasyon grupları örnek olarak verilebilir. Komiteler, yönetim grupları, delege komiteleri, ekipler, tedavi konferansları ve sosyal eylem grupları ise görev gruplarının örnekleridir. ${ }^{35}$ Cinsel saldırı mağduru kadınlarla gerçekleştirilen grup çalışmalarında da mağdurun eğitilmesi, güçlendirilmesi ya da saldırının acısından kurtarılarak tedavi edilmesi amaçlanabilir.

Cinsel saldırıya maruz kalma, travmatik bir deneyim olarak değerlendirildiğinde, travma mağdurları için işlevsel olan grup çalışmalarının bu alanda sıklıkla kullanıldığ sonrasında ailesine, arkadaşlarına, aşka ve topluma karşı bağlanma sorunu yaşayan birey, grubun bir üyesi olarak bu ilişkileri tekrar inşa etme firsatı bulur. ${ }^{41}$ Cinsel saldırı mağdurlarıyla gerçekleştirilen grup çalışmasının, grup üyeleri üzerindeki etkileri şu şekilde sıralanabilir: ${ }^{42}$

Hafıza Kaybı: Birey, uğradığı tecavüz olayını anlatmada büyük zorluk çeker, olayın vahametiyle neler olduğunu zor hatırlar. Ama grup içinde herkes tecrübesini anlattıkça hafizası açılır daha da netleșir.

Hafızayı Duygulara Karıştırma: Travma neticesinde, bazıları olayı anlatırken hiç etkilenmemiş gibi neler olduğunu teker teker anlatacak, bazıları ise korku duygularıyla konuşamayacaktır. Burada, tedavinin ikinci önemli amacına ulaşılmış olunacaktır. Tecavüzle ilgili hafızadaki bilgiler, etkilerle ve geçmişle ilişkilendirilecektir.

Etkiye Katlanma: Üçüncü amaç olan travmatik olayla ilgili sebep ve duygular katlanılabilir hale gelmiştir. Cinsel saldırıdan hemen sonraki yoğun duygulara katlanılabilmektedir.

Semptom Uzmanlığı: Grup tedavisinin diğer bir amacı da, travma sonrası semptomların azalması veya baş edilebilir hale gelmesidir. Daha katlanılabilir daha kolay tespit edilebilir ve mantıki olarak kontrol edilebilir.
Kendine Saygı: Hiçbir tedavi, kendine saygının yeniden kazandırılmasından daha etkili olamaz. $\mathrm{Bu}$ tedaviyle suçluluk duygusu, kendini suçlama ve utanç yerini, kendi değerini anlama ve kişisel değere bırakır.

Bağlılık: Grup tedavisinin son amacı, yalnızlık ve utançla mücadele etme ve böylece kendisiyle beraber aynı tecrübeyi yaşayan grup üyelerini tanıma, çare arama ve güvenme duygusunu kazanmaktır. Birçok mağdur için grupta yer alan bu üyeler ilk güveneceği kișiler olacaktır. ${ }^{42}$

Sosyal hizmette grup uygulamalarına özgü karşılıklı yardım (mutual help) süreci, grup üyelerinin kendi deneyimlerinden yola çıkarak, diğer grup üyelerine yardım etmesi ve derinleşmesi şeklinde gerçekleşir. $\mathrm{Bu}$ yardım sürecinde, grup üyesi yeniden yaşayarak, yeniden öğrenecek ve daha güçlü olacaktır. ${ }^{43}$ Diğer bireylerle eşitlikçi bir ortamda karşılaşma şansı bulan cinsel saldırı mağdurları, bu deneyimi günlük yaşamlarına da genelleme imkânına sahip olacaktır. ${ }^{42}$

Cinsel saldırı sonrası müdahalede grup çalışmalarının kullanılması mağdurların suçluluk, utanma, öfke gibi duygularının grup ortamında paylaşılmasına olanak sağladığı için önemli bir sosyal hizmet uygulaması olarak ön plana çıkmaktadır. Grup ortamı sayesinde cinsel saldırı mağduru diğer insanlarla iletişime geçmek, onlara güvenmek için önemli adımlardan birini atmış olur. En önemlisi, benzer deneyimleri yaşayan grup üyeleriyle bir araya gelerek diğer grup üyelerinin durumundan hareketle kendi iyileşme süreçleriyle ilgili bir fikir edinme şansı yakalarlar.

Sosyal hizmet uzmanı, grup sürecinde gerçekleştirdiği uygulamalarda bir yandan cinsel saldırı mağdurunun güçlendirilmesiyle ilgili çalışırken, diğer yandan yasal prosedür ve hakları konusunda bilgilendirilmesi, cinsel konulara ilişkin tabu olarak kabul edilen konuların konuşulması gibi alanlarda da katkı verir. Ayrıca bu katkı özellikle bu alanda gerçekleştirilen feminist grup çalışması aracılığıyla da gerçekleştirilmektedir. Özellikle kadın haklarının savunulması konusunda sosyal hizmet literatüründe önemli bir yeri olan feminist yaklaşım cinsel taciz ve sömürünün toplumdaki tüm kadınları etkilediğini ve bu durumun, cinsiyetçi bir bakışın gelişmesine neden olduğunu vurgular. ${ }^{44}$

\section{Cinsel Saldırı Măğdurlarıyla Makro Düzeyde Tıbbi Sosyal Hizmet Uygulamalart}

Tıbbi sosyal hizmet uygulamaları kapsamında cinsel saldırı mağdurlarıyla gerçekleştirilen sosyal hizmet uygulamaları, bireysel ve grup düzeyinde yapılan çalışmalarla sınırlı kalmamaktadır. Mağdurlarla bire bir çalışan sosyal hizmet uzmanı, 
uygulamadan edindiği tecrübeleri politika geliştirme sürecine ve toplumsal boyuta taşımakla da sorumludur. Sosyal hizmet uzmanı toplumsal düzeyde "değişim ajanı" rolüyle kurumsal ve toplumsal düzeyde değişimin yaratılmasına katkıda bulunur. ${ }^{45}$

Cinsel saldırı mağduru kadın için en önemli aşamalardan ve iyileşme göstergelerinden biri ait olduğu topluma ve çevresine dönüş aşamasıdır. ${ }^{46} \mathrm{Bu}$ nedenle, sadece mağdurlarla yapılan çalışmalar sorunun çözümünde tek başına yeterli değildir. Topluma yönelik farkındalık çalışmalarına dahil olmak ya da cinsel saldırı ile ilgili proje geliştirme süreçlerinde etkin rol almak önemlidir. Cinsel saldırının tam olarak ne olduğu, hangi durumları kapsadığı, altında yatan nedenler, saldırı mağdurlarını nasıl etkilediği ile farklı kurum ve kuruluşlarda çalışan ve bir şekilde cinsel saldırı mağdurlarıyla yüz yüze gelen profesyonelleri ve tüm toplumu kapsayıcı bir farkındalık ve alg1 oluşturulmasıyla mümkün olabilir. Öncelikle toplumda cinsel şiddete maruz kaldığ 1 halde bu durumu şiddet olarak tanımlamayan, şiddeti sadece fiziksel müdahale çerçevesinde ele alan bir zihniyetin değiştirilmesine yönelik çalışmalar ve düzenlemeler ilk adım olarak gerçekleştirilebilir. Sosyal hizmet uzmanı, bu çerçevede toplumsal cinsiyete ilişkin farkındalık çalışmaları yaparak, cinselliğin konuşulabildiği eğitim ortamları yaratarak, şiddet konusunda farklı kitle iletişim araçlarını kapsayacak projelerin geliştirilmesinde aktif görev alarak cinsel şiddete mağdur boyutundan bir yaklaşım geliştirilmesinde danışmanlık ve kaynak geliştirici rolleri ile katkı sağlayabilir.

Güler, Tel ve Tuncay $^{47}$ tarafindan, kadınların kadına yönelik şiddete bakış açılarının ortaya çıkarılması amacıyla gerçekleştirilen bir çalışmada, çalışmaya katılan kadınların, şiddetin tanımı içinde ekonomik ve cinsel şiddetin olmadığı, kadınların bu iki önemli şiddet türünden bahsetmedikleri ve çoğunlukla fiziksel şiddeti işaret ettikleri görülmüştür. Yine evli kadınların şiddete bakış açıları ile ilgili yapılan bir diğer çalışmada, kadınların \%88,1'i şiddet olarak fiziksel şiddeti tanımlamışlardır. ${ }^{48}$ Araştırmacılar, bunun sebebi olarak kadınların şiddet kavramının kapsamına dair bilgi eksikliğine vurgu yapmışlardır. Ayrıca, eşler arasında yaşanan cinsel şiddete ilişkin deneyimlerin, aile yapısının doğası içinde değerlendirilmesi ya da yabancılar ile konuşulmayacak derecede mahrem sayılmasının da etkili olabileceğinin altı çizilmiştir. ${ }^{47}$

Makro sosyal hizmet boyutunda gerçekleştirilecek sosyal hizmet uygulamalarında, sosyal hizmet uzmanının önemli rollerinden biri de yasal süreçler üzerinde doğrudan ya da dolaylı müdahale sağlayacak çalışmaları planlamak, organize etmek ve gerçekleştirmektir. Sosyal hizmetin, toplumsal değişimi yaratma sürecinde önemli bir adım olan yasalarda gerçekleştirilen düzenlemeler ve cinsel saldırı konusundaki iyileştirmeler bu konuya ilişkin önemli katkı sağlar.

Konuya ilişkin mevzuat incelendiğinde, Kadına Yönelik Her Türlü Ayrımcılığın Önlenmesi Uluslararası Sözleşmesi- CEDAW ${ }^{49}$ (Birleşmiş Milletler), Pekin Deklarasyonu ${ }^{50}$, Kadına Yönelik Şiddet ve Aile İçi Şiddetin Önlenmesi ve Bunlarla Mücadeleye İlişkin Avrupa Konseyi Sözleşmesi ${ }^{51}$ (İstanbul Sözleşmesi) gibi uluslararası metinlerle karşılaşılmaktadır. Bu metinlerin oluşturulması ve sonrasinda ulusal mevzuata uyarlanması aşamasında sosyal hizmet uzmanları uluslararası ve ulusal düzeyde hak savunuculuğu rolü ile etkin bir şekilde rol almış ve süreci takip etmiştir. Geçmişte örnek olarak, ülkemizde evlilik içi tecavüzlerin yasal bir suç sayılmasına ilişkin yasal düzenlemenin değiştirilmesinde hukuk, tıp, hemşirelik, psikoloji, sosyoloji, antropoloji gibi birçok meslek mensubu ile birlikte sosyal hizmet uzmanlarının da bireysel ve kurumsal düzeyde önemli bir rolü vardır. Uluslararası düzeyde ise sosyal hizmet mesleğinin makro boyutunda yaptığı çalışmalar ve felsefi yaklaşımı ile kadın hareketinin birçok boyutunda aktif rol alan ve makro sosyal hizmet uygulamalarında önemli bir yere sahip olan Jane Addams, sosyal hizmet uzmanının politik olarak aktivist rolüne dikkat çeken bir öncü olarak örnek verilebilir. ${ }^{52}$

Cinsel saldırılarla ilgili politika belgeleri incelendiğinde, bu konuyu kadına yönelik şiddet kapsamında ele alan Kadına Yönelik Şiddetle Mücadele Eylem Planı (2016-2020) ile karşılaşılmaktadır. ${ }^{53}$ Kadına Yönelik Şiddetle Mücadele Eylem Planı'nda, 2016 ile 2020 yılları arasındaki dönemi kapsayan ulusal hedefler beş başlıkta ele alınmıştır. Konuya ilişkin mevzuatın geliştirilmesi, farkındalık çalışmaları, koruyucu önleyici hizmetlerin etkililiğinin artırılması ve mağdurların sosyo-ekonomik olarak güçlendirilmesi, şiddetin tüm taraflarına yönelik sağlık hizmetlerinin düzenlenmesi ve bu konuya ilişkin kurumlar arası işbirliğinin güçlendirilmesi ve politika geliştirilmesi olarak özetlenebilecek ulusal hedeflerde paydaş kurumlardan biri de Sağlık Bakanlığı'dır. Özellikle sağlık hizmetlerinin düzenlenmesi ve uygulanması hedefi kapsamında, Sağlık Bakanlığı sorumlu kurum olarak işaret edilmektedir. $\mathrm{Bu}$ bölümde yer alan faaliyetlerden biri, İstanbul Sözleşmesi gereğince, cinsel şiddet mağdurları için özel hizmet modellerinin oluşturulması ve uygulamaya geçirilmesine yer verilmiştir. Ayrıca bir diğer faaliyet olarak, 6284 sayılı Kanun kapsamında hakkında önleyici tedbir kararı verilen şiddet uygulayanlara yönelik rehabilitasyon ve destek programları uygulamak 
üzere psikososyal destek merkezlerinin kurulması ve kapasitesinin geliştirilmesi hedeflenmiştir. $\mathrm{Bu}$ çerçevede, cinsel şiddete yönelik Sağlık Bakanlığı'nın sorumluluğunun sadece fiziksel tedavi ile sınırlandırılmadığı ve psikososyal alana da vurgu yapıldı̆̆ 1 görülmektedir. $\mathrm{Bu}$ durum, bu süreçte tıbbi sosyal hizmet uygulamalarının birey, grup ve toplum düzeyinde cinsel saldırı mağdurlarını da kapsayacak şekilde sağlık hizmetleri içinde önemli bir yeri olduğuna ilişskin algıyı pekiştirmektedir.

\section{SONUÇ VE ÖNERÍLER}

Cinsel saldırı, mağdur kadınların ışık tutmasıyla beraber 1970'li y1llardan itibaren bir sosyal sorun olarak gündeme gelmiştir. ${ }^{6} \mathrm{Bu}$ tarihten itibaren toplumsal değişimle birlikte kadının toplumdaki konumunun değişmesi, kadın hakları konusundaki gelişmelerle birlikte öncesinde yok sayılan, konuşulmayan bir konu olan cinsel saldırılar her yönüyle konuşulmaya başlamıştır. Özellikle kadın hareketlerinin etkisiyle, kadınların cinsel saldırılarla ilgili deneyimlerini daha rahat bir şekilde ifade etmeye başlamaları, tüm resmi bütün gerçekliğiyle yansıtmasa da konuya ilişkin genel bir tablonun açığa çıkmasına yol açmıştır. Önce uluslararası alanda, ardından da ülkelerin iç mevzuatında konuya daha çok yer vermeleri ve kadınların haklarının teslim edilmesiyle birlikte cinsel saldırı mağdurlarına ilişkin yeni hizmet modelleri de geliştirilmeye başlamış, tüm kuruluşlar kendi hizmet alanları dâhilinde sürece dâhil olmuşlardır. $\mathrm{Bu}$ durum, çalışmanın odak noktası olması itibariyle özellikle sağlık hizmetlerinde konuya ilişkin duyarlılığın artmasına, yeni düzenlemelerin yapılmasına, çok yönlü ve disiplinler arası bir bakış açısıyla müdahalelerin çeşitlendirilmesine yol açmıştır. Sağlık hizmet sunumunun tüm boyutlarında ve bu süreçte aktif rol alan aile hekimleri, halk sağlığı uzmanları, kadın doğum uzmanları, psikiyatristler gibi sağlık profesyonellerinin hemen, hemen tamamı aynı zamanda hemşireler, paramedikler, psikologlar ve sosyal hizmet uzmanlarının hem cinsel saldırı olgusuna, hem de cinsel saldırıya maruz kalmış bireye karşı farkındalıklarının yüksek olması gerekmektedir. Özellikle cinsel saldırı sonrasında, bireyin vücut bütünlüğunün bozulmuş olma ihtimali ve özel alanın ihlal edilmiş olması nedeniyle fiziksel muayene ve girişimsel işlemler sırasında mağdura yaklaşımda hassas olunmalı ve yaşadığ1 süreç dikkate alınmalıdır. Cinsel saldırı mağdurlarının fiziksel tanı ve tedavisinde, psikolojik, sosyal ve ekonomik ihtiyaçlarını karşılamak üzere konuya ilişkin duyarlı bir ekip tarafından sunulacak sağlık hizmetinin, cinsel saldırı mağdurlarının yaşayacağı muhtemel ikincil örselenmelerin önüne geçeceği düşünülmüştür.
$\mathrm{Bu}$ genel çerçevede, cinsel saldırı mağdurlarıyla bire bir yapılan mikro düzeyde müdahalenin yanında, grup ortamında ve toplumsal düzeyde yapılan sosyal hizmet müdahalelerinin bir bütün olarak sağlık alanında önemli bir yeri vardır. $\mathrm{Bu}$ nedenle, bu uygulamayı gerçekleştiren sosyal hizmet uzmanlarının cinsel saldırıyla ilgili mevzuata ve diğer kurum ve kuruluşların verdiği hizmetlere hâkim olması, danışmanlık, arabuluculuk, hak savunuculuğu, harekete geçiricilik gibi rollerini ön planda tutması gerekmektedir. $\mathrm{Bu}$ çerçevede Sağlık Bakanlığ tarafından hizmet içi eğitimler kapsamında, cinsel saldırı ile çalışan tüm meslek elemanlarına ve bu grubun içinde sosyal hizmet uzmanlarına yönelik hizmet içi eğitimler düzenlenmesinin, verilen hizmetin niteliğini geliştireceği düşünülmektedir. Ayrıca, cinsel saldırı mağdurlarıyla çalışan ekip üyelerine, tüm ekip üyelerinin rolleri ve sorumluluklarıyla ilgili bilgilendirici etkinliklerin düzenlenmesi disiplinler arası çalışmanın etkinliğini arttıracaktır.

\section{KAYNAKLAR}

1. Okumuş, E. Bedene müdahalenin sosyolojisi, K. Canatan (Ed.), Beden Sosyolojisi (1. Baskı) içinde (45-67), 2011, İstanbul: Açılım Kitap, p.45-67.

2. User, İ. Biyoteknolojiler ve kadın bedeni, Y. İnceoğlu ve A. Kar (Ed.). Dişilik, güzellik ve şiddet sarmalında kadın ve bedeni (1. Baskı) içinde (133-169), 2010, İstanbul: Ayrıntı Yayınları, p.133-169.

3. World Health Organization. Sexual violence. In: World report on violence and health. Geneva, 2002, Retrieved Dec 12, 2017, from http://whqlibdoc.who.int/publications/2002/92 41545615_eng.pdf., p.149.

4. Dumrul, C., Karabacak Danac1, H. Kadın ve kız çocuklarına karşı işlenen cinsel şiddet suçlarında cezasızlık sorunu raporu. Ankara Barosu Dergisi, 2015, 4, 255-290.

5. Davis, A. Kadınlar, ırk ve sınıf. Çev: İnci Çekiner, 1994, İstanbul: Sosyalist Yayınlar, p.165, 188-189.

6. Scully, D. Cinsel şiddeti anlamak: Tutuklu tecavüzcüler üzerine bir inceleme. çev: Şirin Tekeli, Laleper Aytek, Kadın Araştırmaları Dizisi-6, 1994, İstanbul: Metis Yayınları, ss. 17, 46, 50-64, 63-64.

7. Buchwald, E., Fletcher, P. R., \& Roth, M. Transforming a rape culture (p. XI), (Eds.), 1993, Minneapolis, MN: Milkweed Editions, p.9.

8. United Nations. Violance Against Women, 2000, Erişim tarihi, 8 Aralı 2017. http://www.un.org/esa/gopherdata/conf/fwcw/pim/feature/2VIOL.TXT. 
9. Randall, M., \& Haskell, L. Sexual violence in women's lives: Findings from the Women's Safety Project, a community-based survey. Violence Against Women, 1995, 1(1), 6-31.

10. Artuk, ME. Kadına yönelik cinsel istismara örnek olarak evlilik içinde irza geçme ve fücur. Kadına Yönelik Cinsel Şiddete Karşılaștırmalı Hukukun Yaklaşımı (içinde), İstanbul: İstanbul Barosu Kadın Hakları Uygulama Merkezi. Yayın no:1, 2002, p. 31-48.

11. Sparks, A. Feminists negotiate the executive branch: The policing of male violence. C. Daniels (Ed.), Feminist negotiate the state: The politics of domestic violence, 1994, Lanham, New York: University Press of America, p.3552.

12. Aile ve Sosyal Politikalar Bakanlığı Kadının Statüsü Genel Müdürlüğü, Hacettepe Üniversitesi Nüfus Etüdleri Enstitüsü. Türkiye'de kadına yönelik aile içi şiddet araştırması özet rapor, 2014, Ankara.

13. Rape Crisis England \& Wales Headline Statistics 2016-17. Erişim tarihi: 5 Aralık 2017, https://rapecrisis.org.uk/statistics.php.

14. Türkiye İstatistik Kurumu, Ceza infaz kurumu istatistikleri, 2017, Erişim tarihi: 20 Kasım 2017 ,

http://www.tuik.gov.tr/PreHaberBultenleri.do?i $\mathrm{d}=18689$.

15. Dunn, SF, Gilchrist, VJ. Sexual assault. Primary Care, 1993, 20(2), 359-373.

16. Abarbanel, G, Richman, G. The rape victim in crisis intervention book 2: The practitioner's sourcebook for brief therapy. Ed. Parad HJ, Parad L, 1990, Family Service America. Milwaukee Wisconsin, p. 93.

17. French, M. Kadınlara karşı savaş. çev: Beril Eyüboğlu, 1992, İstanbul: Metis Yayınları, p. 243,246

18. Arın, C. Kadına yönelik cinsel şiddet. Kadına Yönelik Cinsel Şiddete Karşılaştırmalı Hukukun Yaklaşımı (içinde), İstanbul: İstanbul Barosu Kadın Hakları Uygulama Merkezi. Yayin no:1, 2002, p. 8-11.

19. Coker, A. L., Smith, P. H., Bethea, L., King, M. R., \& McKeown, R. E. Physical health consequences of physical and psychological intimate partner violence. Archives of family medicine, 2000, 9(5), 451-457.

20. Eby, K. K., Campbell, J. C., Sullivan, C. M., \& Davidson, W. S. Health effects of experiences of sexual violence for women with abusive partners. Health Care for Women International, 1995, 16(6), 563-576.

21. Jewkes, R., Sen, P. and Garcia-Moreno, C. 'Sexual violence', in Krug, E. G., Dahlberg, L. L., Mercy, J. A., Zwi, A. B., and Lozano, R. (eds.), 2002, World report on violence and health. Erişim tarihi: 20 Kasım 2017, http://www.who.int/violence injury prevention/ violence/world report/en/.

22. Darves-Bornoz, J. M. Rape-related psychotraumatic syndromes. European Journal of Obstetrics \& Gynecology and Reproductive Biology, 1997, 71(1), 59-65.

23. Fergusson, D. M., Horwood, L. J., \& Lynskey, M. T. Childhood sexual abuse and psychiatric disorder in young adulthood: II. Psychiatric outcomes of childhood sexual abuse. Journal of the American Academy of Child \& Adolescent Psychiatry, 1996, 35(10), 1365-1374.

24. Kilpatrick, D. G., Resick, P. A., \& Veronen, L. JEffects of a rape experience: A longitudinal study. Journal of Social Issues, . 1981, 37(4), 105-122.

25. Resick, P. A., Calhoun, K. S., Atkeson, B. M., \& Ellis, E. M. Social adjustment in victims of sexual assault. Journal of Consulting and Clinical Psychology, 1981, 49(5), 705.

26. Adalet Bakanlığı Mağdur Hakları Daire Başkanlığı. Mağdura yaklaşım kılavuzu. Adalet Bakanlığı Mağdur Hakları Daire Başkanlığı Yayın No: 02, 2016, Ankara: Analitik Reklam, p.20.

27. Wiseman, R. Cinsel şiddet ve tecavüze karşı kendimizi savunurken: Yaşananlar, önlemler ve günlük yaşama geri dönüş el kitabı. çev: Lale Akalın, 1994, İstanbul: Sel Yayıncılı, p. 157

28. Sağlık Bakanlığı Tıbbi Sosyal Hizmet Uygulama Yönergesi, 2011, Erişim tarihi: 23 Kasim 2017 , http://www.hasta.saglik.gov.tr/TR,4778/tibbisosyal-hizmet-uygulama-yonergesi.html.

29. Ünlü Akyollu, İ. Psikososyal destek ve krize müdahale birimine ilişkin Sakarya örneğinde bir değerlendirme. Yayınlanmamış Yüksek Lisans Tezi, 2015, Kocaeli Üniversitesi Sosyal Bilimler Enstitüsü, Kocaeli, p.65.

30. Katz, J. H. The healing process after rape. 1993, Saratoga, California: R\&E Publishers, p.79-86.

31. Özdemir, U. Kriz, krize müdahale ve kriz tedavisi. Acil Sağlık Hizmetlerinde Sosyal Hizmet Çalışmaları Panel Kitapçı̆̆ı içinde, Ed. (A. Kaya, E. Özkan, AH, Türkdemir), 2012, 79-84.

32. Teater, B. Sosyal hizmet kuram ve yöntemleri: Uygulama için bir giriş. Çev. Ed. A. Karatay, 2015, Ankara: Nika Yayınevi, p.231, 267.

33. Turan, N. Bireylerle ve ailelerle sosyal hizmet. Ankara, 2012, Sosyal Hizmet Uzmanları Derneği Genel Merkezi Yayını, p.298-299, 302.

34. Sayıl, I. Ruh sağlığı sorunu olarak şiddet. Kriz Dergisi, 2000, 2(2): 273-276.

35. Mavili Aktaş, M. Küçük gruplar: Dinamikleri ve süreci, 2001, Ankara, Mustafa Kitabevi, p.37, $42-58$. 
36. Topses, G. Bulut Serin, N. Psikolojik danışma ve kişilik kuramları, 2012, Ankara, Nobel Akademik Yayıncılık, p.89, 1-32.

37. Duyan V. Sosyal Hizmet Temelleri Yaklaşımları Müdahale Yöntemleri. Ankara, Sosyal Çalışma Yayınları, 2014, p.294.

38. Thompson, N. Kuram ve uygulamada sosyal hizmeti anlamak. Ankara, Dipnot Yayınevi, 2016, p.42.

39. Kirst-Ashman, K., Hull, G.H. Understanding generalist practice. Second Edition, 1999, Chicago: Nelson-Hall Publishers, p.91-94.

40. Duyan, V., Özgür Sayar, Ö., Özbulut, M. Sosyal hizmeti tanımak ve anlamak, 2008, Ankara, Öncü Basımevi, p.90, 96.

41. Herman, J. Trauma and recovery. 1997, New York: Basic Books. p..49

42. Koss, M. P., \& Harvey, M. R. The rape victim: Clinical and community interventions, 1991, Newbury Park, California: Sage Publications, Inc, 205-223.

43. Kurland, R. and Salmon, R. Group work vs. casework in a group: Principles and implications for teaching and practice. Social Work with Groups, 1992, 15(4), 3-10.

44. Yassen, J. And Glass, L. Sexual assault survivor groups: A feminist practice perspective. Social Work (May/June), 1984, 252-257.

45. Sheafor, B. W., Horejsi, C. R., \& Horejsi, G. A. Techniques and guidelines for social work practice, Sixth Edition, 2002, Boston: Allyn \& Bacon, Inc. p.89.

46. Erdal, M. Gözaltında tecavüz, 1997, İstanbul, Çiviyazıları, p.50.

47. Güler, N., Tel, H., \& Tuncay, F. Ö. Kadının aile içinde yaşanan şiddete bakışı. CÜ Tıp Fakültesi Dergisi, 2005, 27(2), 51-56.

48. Efe, Ş. Y., \& Ayaz, S. Kadına yönelik aile içi şiddet ve kadınların aile içi şiddete bakışı. Anadolu Psikiyatri Dergisi, 2010, 11(1), 23-29.

49. Birleşmiş Milletler, Kadına karşı her türlü ayrımcılığın önlenmesi uluslararası sözleşmesi, Erişim tarihi: 19 Şubat 2018, https://www.unicef.org/turkey/cedaw/_gi18.ht $\mathrm{ml}$.

50. Birleşmiş Milletler, Pekin Deklarasyonu ve Eylem Planı, Erişim tarihi: 19 Şubat 2018, https://www.tbmm.gov.tr/komisyon/kefe/docs/ pekin.pdf.

51. Kadınlara Yönelik Şiddet ve Ev İçi Şiddetin Önlenmesi ve Bunlarla Mücadele Hakkındaki Avrupa Konseyi Sözleşmesi, http://www.resmigazete.gov.tr/eskiler/2012/03/ 20120308M1-1.pdf.

52. Knight, L. W. Jane Addams: Eylemci bir ruh. 2014, (Çev. Ed. Özlem Cankurtaran Öntaş) Ankara: Ayizi Kitap.

53. Aile ve Sosyal Politikalar Bakanlığı Kadının Statüsü Genel Müdürlüğü Kadına yönelik şiddetle mücadele ulusal eylem planı (20162020). Erişim tarihi: 24 Kasım 2017, http://kadininstatusu.aile.gov.tr/ulusal-eylemplanlari/kadina-yonelik-siddetle-mucadeleulusal-eylem-plani. 